Moreira-JACOB, M. (1956). J. gen. Microbiol. 14, 268-280

\title{
The Streptococci of Lancefield's Group E; Biochemical and Serological Identification of the Haemolytic Strains
}

\author{
BY M. MOREIRA-JACOB* \\ The National Institute for Research in Dairying, University of Reading
}

SUMMARY: The non-pathogenic beta-haemolytic streptococei from milk, forming Lancefield's group E, were physiologically defined as Streptococcus infrequens and S. subacidus. They were found to fall into four serological types. Fractionation with ethanol showed that both group- and type-specific fractions of these organisms are of polysaccharide nature which probably accounts for the success in using formamide extracts for the type-precipitin reactions. S. subacidus possesses two type antigens, only one of which is also found in S. infrequens.

Little attention has been paid to serological group $\mathbf{E}$ since Lancefield identified its group-specific antigen (1933). Isolation of several strains was reported by Newson (1937), Gunnison, Luxen, Marshall \& Engle (1940), Plummer (1941), Stafseth \& Clinton (1941), Coffey (1942), and, more recently, by Collier (1951), Thal \& Moberg (1953) and others. However, no substantial contribution has yet been made either to the type division of this group or to the chemical nature of the antigenic fractions responsible for its serological pattern. Topley \& Wilson's Principles (1946) mention, in a table, that both type and group substances are polysaccharides; also that several specific types have been recognized, but reference is not made to the work leading to such findings. The only relevant literature found was a personal communication of Lancefield to Stafseth \& Clinton (1941) in which she admitted the existence of more than one type.

\section{METHODS}

Source of cultures. Altogether twenty haemolytic streptococci were collected for study. I am indebted to Mr F. K. Neave for six strains (with the suffix E) isolated during the course of this investigation; to Dr Julia Coffey for six strains (with the suffix CO) isolated during the period 1934 to 1942 ; to Dr H. J. Stafseth for the 'Newson' strain. The remaining seven strains were stock cultures kept at the National Institute for Research in Dairying; these included strains K 128, K129 and K131 isolated about 1925 by Dr J. A. Brown (Lancefield, 1933) and two strains, C24 A and C24B isolated by Dr Stafseth and received from Dr Lancefield. The streptococci were obtained from milk with the following four exceptions: 4051 CO, isolated in 1940 by Dr Julia Coffey (personal communication) from drainage of wound on the hand of a dairy worker; 'Newson' isolated from a cervical suppurating lymph gland of a pig (Newson, 1937); C24A and C24B isolated from abscessed lymph nodes of swine by $\operatorname{Dr}$ H. J. Stafseth.

* Present address : Central Veterinary Laboratory, Department of Agriculture, Benfica, Lisbon, Portugal. 


\section{Biochemical and cultural tests}

Haemolysis was tested by streaking $18 \mathrm{hr}$. cultures on $5 \%$ horse-blood agar with a basal medium of $2 \%(\mathrm{w} / \mathrm{v})$ agar, $1 \%$ peptone (Evans), $1 \%$ Lab-Lemco and $0.5 \% \mathrm{NaCl}$. The plates were incubated for $48 \mathrm{hr}$. at $37^{\circ}$.

Reducing properties. Reactions in litmus milk and methylene blue milk $(1: 5000)$ were recorded after 5 days of incubation at $37^{\circ}$, with preliminary readings after 24 and $48 \mathrm{hr}$.

Carbohydrate fermentations. Seitz-filtered $0.5 \%(\mathrm{w} / \mathrm{v})$ 'sugar' solutions (except aesculin) were added to peptone water containing $1 \%$ Andrade's indicator and $1 \%$ ox serum.

Hydrolysis of sodium hippurate. This test was carried out as applied by Davis, McClemont \& Rogers (1939). A further modification was made: $1 \mathrm{ml}$. of the sterile hippurate broth was added to tubes with progressive numbers of drops of $12 \% \mathrm{FeCl}_{3}$ solution containing $2.5 \mathrm{ml}$. of concentrated $\mathrm{HCl} / 1$.; after agitation, the first clear tube in the scale was noted. The presence of benzoic acid was then determined by adding $1 \mathrm{ml}$. of culture to the recorded number of drops of reagent.

Growth at $45^{\circ}$. Tubes of glucose $1 \%$ Lemco broth and yeast glucose litmus milk were seeded, incubated in a $45^{\circ}( \pm 0 \cdot 1)$ water-bath and examined for growth after $24 \mathrm{hr}$.

Survival at $60^{\circ}$ for $30 \mathrm{~min}$. Tubes of glucose Lemco broth were warmed at $55-59^{\circ}$, inoculated and held for exactly $30 \mathrm{~min}$. in a water-bath at $60^{\circ}( \pm 0 \cdot 1)$, cooled immediately and incubated at $37^{\circ}$ for $24 \mathrm{hr}$.

Growth at $\mathrm{pH} 9 \cdot 6$. The technique of Shattock \& Hirsch (1947) was used.

Inoculations. All the liquid media were seeded with 1-2 drops of an $18 \mathrm{hr}$. culture. Readings were made on the fifth day of incubation.

\section{Serological methods}

The medium generally used for all serological purposes was glucose $(0.5 \%)$ Lemco broth.

Preparation of antisera. Cocci suspended in saline were heat-killed at $57^{\circ}$ for $30 \mathrm{~min}$. or killed in $\mathbf{0 . 2 5} \%$ formalin (Lancefield, 1933). Cocci twice washed in acetone and dried in vacuum over $\mathrm{P}_{2} \mathrm{O}_{5}$ were then ground in a ball mill under cold water (Shattock \& Mattick, 1943). The stock vaccines were diluted to the opacity of Brown's tube no. 7 (Burroughs Wellcome \& Co.), fresh dilutions being made for each injection. Inoculations were performed every 3 or 4 days, the first dose being $0.5 \mathrm{ml}$., the second $1 \mathrm{ml}$., and thereafter $1.5 \mathrm{ml}$.

\section{Precipitin test}

Formamide extracts. Fuller's (1938) method was carried out by extracting the cocci of $5 \mathrm{ml}$. culture with $1.0 \mathrm{ml}$. formamide at $150^{\circ}$ for $15 \mathrm{~min}$.; $2.5 \mathrm{ml}$. acid ethanol was added, the resulting precipitate discarded and the clear supernatant mixed with $5 \cdot 0 \mathrm{ml}$. acetone. The precipitate formed was dissolved in $1.0 \mathrm{ml}$. saline. 
Crude $\mathbf{H C l}$ extracts. Sediments of $100 \mathrm{ml}$. cultures were extracted in $2.5 \mathrm{ml}$. $0.05 \mathrm{~N}-\mathrm{HCl}$ in saline (Lancefield, 1933). Extracts resistant to clarification by spinning were treated with a few drops of trypsin solution and incubated for $2 \mathrm{hr}$., boiled for $5 \mathrm{~min}$. and then centrifuged. This was the most successful method among several tried.

Antigenic fractions. Pure solutions of group and type substances were obtained by extracting the twice-washed sediments with $0.05 \mathrm{~N}-\mathrm{HCl}$ in saline. The organisms were attacked a second time with $0 \cdot 2 \mathrm{~N}-\mathrm{HCl}$ in distilled water, the stronger acid solution being applied to overcome the increased cellular resistance. To both first and second crude extracts, neutralized, centrifuged and kept separated, were added four volumes of ethanol and then they were stored in the cold. After centrifugation, the ethanolic supernatants were kept in the cold overnight and the protein precipitate dissolved in $2.0 \mathrm{ml}$. saline and reprecipitated with three volumes ethanol, ethanol washings being repeated until the Molisch reaction was negative. The combined supernatants were evaporated and the dried C-substance treated with ethanol until the biuret reaction was negative. When finally separated, both fractions from 11 . cultures were dissolved in $3.0 \mathrm{ml}$. saline, neutralized, centrifuged and kept in the cold with $1 / 10(\mathrm{v} / \mathrm{v})$ of $5 \%$ carbol-saline.

Specific precipitation sera. Non-specific group or type antisera were absorbed respectively with group or type cross-reacting strains. One volume of packed heterologous cells, heat or formol killed, was emulsified with two/three volumes of undiluted serum and the suspension left in the water-bath at $37^{\circ}$ for $30 \mathrm{~min}$., repeatedly shaken and centrifuged. The sediment was left in the tube and, if proper absorption was not achieved, the cocci were again emulsified, the mixture immersed in the water-bath for $2 \mathrm{hr}$. and left overnight in the cold. When heterologous antibodies were not eliminated, another cross-reacting strain was tried with a fresh volume of antiserum.

Precipitin reactions. The extract was layered on the antiserum in a precipitin tube of $2 \mathrm{~mm}$. internal diameter and the rings recorded within 1 to $5 \mathrm{~min}$.

\section{The type-agglutinin reaction}

Water-bath agglutination. Dreyer's technique was followed using equal amounts (10 drops) of reagents, the tubes being left in a water-bath at $50^{\circ}$ and read after 4 and $18 \mathrm{hr}$. Cultures in glucose $(0 \cdot 1 \%)$ Lemco broth, usually $16 \mathrm{hr}$. old, containing 20,000-40,000 $\times 10^{6}$ organisms $/ \mathrm{ml}$, and killed by formalin $(\mathbf{0 . 2 5} \%)$ were used as antigens. Auto-agglutinability was generally overcome by heavy seeding and incubation for 6-8 hr. with occasional shaking, a method which proved the most suitable among several tried.

Slide agglutination. For this test, serum was diluted to $1 / 32$ of its (waterbath) titre. A 'slide end-titre' was also used following De Waal's procedure (1940); serum was added drop by drop to $2.0 \mathrm{ml}$. carbol-saline until good clumping was observed within 10-20 sec. with the homologous suspension. Sera of low agglutination content were dropped into $1 \mathrm{ml}$. carbol-saline. Bacterial antigens were suspensions of cocci in carbol-saline, with an opacity of roughly five times Brown's tube no. 7; denser opacities tended to make 
readings difficult. Reactions appearing later than 2 min. (only seldom observed) were taken as non-specific. Spontaneous granularity was sometimes successfully prevented by incubating the cocci with a few drops of trypsin solution until instability could no longer be observed.

Specific agglutinating antisera. The heterologous agglutinins were eliminated by mixing undiluted serum with packed organisms of the absorbing strain in a manner similar to that applied to sera for the precipitin test, the end-titre dilution being obtained by the technique of De Waal (1940). In a second method, the serum was first diluted to $1 / 64$ of its titre and mixed with an equal quantity of a suspension of formol-killed organisms in carbol-saline with an opacity 10 times that of Brown's tube no. 7. The tube was incubated in a $37^{\circ}$ water-bath for $30 \mathrm{~min}$., $2 \mathrm{hr}$. or left overnight in the cold if cross-reactions were not eliminated by the first two treatments. The actual dilution of the serum was $1 / 32$ of its titre.

\section{RESULTS}

\section{Biochemical and physiological reactions}

Seventeen of the twenty strains collected for this study formed a group (subsequently referred to as Streptococcus infrequens) with the following characters (Table 1): fermentation of sucrose, salicin, mannitol, sorbitol, trehalose and hydrolysis of aesculin; no action on inulin and raffinose; litmus milk was generally acidified, but five strains were able to coagulate the medium with slight reduction; the action on methylene blue milk was irregular, and nine strains reduced the dye, four of them with further coagulation; the reaction on sodium hippurate was negative in all but three strains which slightly hydrolysed this substance. The three remaining streptococci (referred to as $S$. subacidus) were differentiated from this group because of their failure to split aesculin, mannitol and salicin; the fermentation of sucrose was irregular; they had no action on methylene blue milk and only slightly acidified litmus milk. Beta-haemolysis with wide and clear zones was produced by the surface colonies of all strains after $48 \mathrm{hr}$. incubation. The colonies did not exhibit any distinctive characteristic except those of the second group which were of 'minute' size. All the strains produced good growth in liquid media after $24 \mathrm{hr}$. incubation at $37^{\circ}$, but 4678 was exceptional in requiring at least $48 \mathrm{hr}$. incubation, perhaps because of the small size of its cocci.

\section{Group reactions}

Extracts of all the strains have given precipitin (ring) reactions with sera of group E. Similar positive results were obtained either with the ordinary crude $\mathrm{HCl}$ or formamide extracts. Experience showed that it is also possible to extract these streptococci with $0 \cdot 2 \mathrm{~N}-\mathrm{HCl}$ in distilled water, a technique applied by Swift, Wilson \& Lancefield (1943) to group A streptococci in order to get stronger concentrations of M substance for type precipitation. These extracts were prepared in the ordinary way except that, for final neutralization, a solution of $1 \% \mathrm{Na}_{2} \mathrm{HPO}_{4}$ in $0 \cdot 2 \mathrm{~N}-\mathrm{NaOH}$, balanced against $0 \cdot 2 \mathrm{~N}-\mathrm{HCl}$, was used. This buffer solution provides a suitable salt concentration for the precipitin 
Survival at $60^{\circ}$, $30 \mathrm{~min}$.

Growth at $\mathrm{pH} 9 \cdot 6$

Growth at $45^{\circ}$

Sodium hippurate
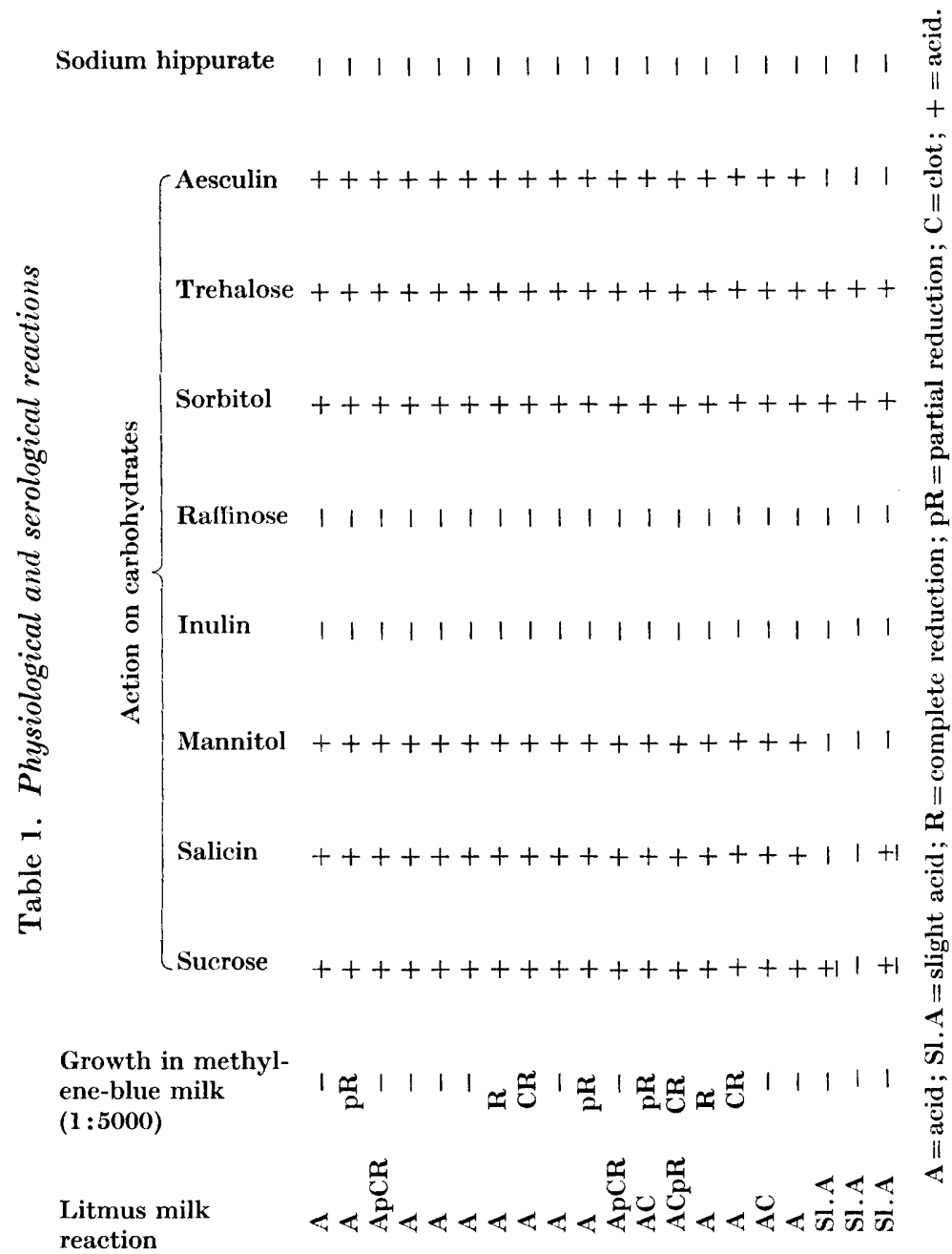

Haemolysis

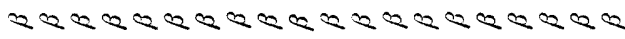

Strains

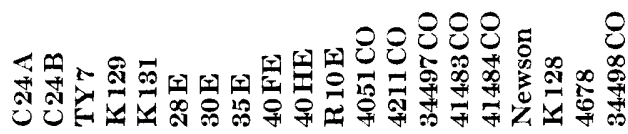


reaction, and in fact the required amount of electrolyte is so small that precipitin rings could even be produced in distilled-water extracts without the addition of buffer. Formamide extracts, either from $5 \mathrm{ml}$. (Fuller's original technique) or from $10 \mathrm{ml}$. culture were also successful. Ring precipitations could still be obtained in extract dilutions of $1 / 5$ to $1 / 20(\mathrm{v} / \mathrm{v})$.

Cross-reactions reported by Lancefield (1933) between her strain K131 and a group $\mathrm{C}$ antiserum could not be confirmed; all the extracts were negative against an antiserum of that group. It was also found that the physiological relationship between the enterococcus and group $\mathbf{E}$ (sorbitol and trehalose are fermented by both groups) was not reflected in serological relationship and all the $\mathrm{E}$ extracts failed to react with a group $\mathrm{D}$ antiserum prepared from a haemolytic strain. The group $\mathbf{D}$ antiserum mentioned in this work was obtained from Streptococcus durans strain $98 \mathrm{D}$ with a suspension of disintegrated (ground) cocci.

Characteristics of group $E$ antisera. Altogether, nine rabbits were inoculated with different suspensions for various periods of time. Serum 273, prepared with formolized cocci of $\mathrm{C} 24 \mathrm{~B}$, showed very strong group-specific antibody content after the fourth injection. Serum 294 was prepared against 4678 , also formol-killed. In the four bleedings, only type-specific antiserum was obtained, but group reactions appeared after thirty inoculations. Immunization was continued, but, in all subsequent bleedings, type-specificity appeared again. Strain TY 7 was chosen for the preparation of the third serum, 227; a suspension made with disintegrated cocci was used, but no response could be obtained in the first three bleedings; after thirty-eight inoculations, the serum showed only strain specificity. It was decided to change the type of suspension and group antibodies appeared after nine inoculations with heat-killed cocci. However, during subsequent immunization, the antiserum again became type-specific and group specificity was not recovered during the course of forty further injections. In the late stages of this work, two other formolized vaccines were prepared from the freshly isolated $28 \mathrm{E}$ and $4211 \mathrm{E}$; their respective antisera, 311 and 312 , showed only type-specific antibodies. Lancefield strains K131 and K129 gave sera which cross-reacted with several extracts of groups $\mathbf{A}-\mathbf{N}$ and also with the nucleoprotein P. Absorption with heavily packed staphylococci did not render these sera specific.

\section{Type reactions}

It was possible to divide the strains into three well-defined types, a fourth type being formed by the strain 'Newson' which did not react with any of the available antisera. Type differentiation, with parallel results, was carried out by the precipitin reaction accompanied by slide and water-bath agglutinations. Acid extraction, either by $0.05 \mathrm{~N}-$ or $0.2 \mathrm{~N}-\mathrm{HCl}$ as well as formamide extraction proved to be satisfactory (Table 2). Some discrepancies arising from the different antibody content of the antisera will be recorded in detail.

Type I. Into type I fell Lancefield strains C24 A, C24 B, K 129 and also the K128. Strain K128 showed auto-agglutinability resistant to several forms of treatment, but a stable suspension was obtained with cocci treated with 
trypsin. Two antisera were available: serum 273 , prepared against $\mathrm{C} 24 \mathrm{~B}$, and serum 250, prepared against K 129. The titre of both sera was $1 / 2560$. Before being satisfactorily absorbed by strain TY 7 the first showed complete group specificity, whereas the second gave positive precipitin reactions with nucleoprotein $\mathrm{P}$; however, both were proved type-specific by the agglutinin tests. The four strains falling into type I exhausted both sera of their homologous antibodies. The $\mathrm{HCl}$ extract of type II strain $28 \mathrm{CO}$ produced a slight crossreaction with antisera of type $I$ which was not observed with the corresponding formamide extract.

Table 2. Type division of haemolytic strains of group $E$

\begin{tabular}{|c|c|c|c|c|}
\hline \multirow[b]{2}{*}{ Strains } & \multicolumn{4}{|c|}{ Types } \\
\hline & I & II & III & IV $\dagger$ \\
\hline C 24.A & + & - & - & . \\
\hline C $24 \mathrm{~B}$ & + & - & - & . \\
\hline K 128 & + & - & - & . \\
\hline K 129 & + & - & - & . \\
\hline K 131 & - & + & - & . \\
\hline TY 7 & - & + & - & . \\
\hline $28 \mathrm{E}$ & - & + & - & . \\
\hline $30 \mathrm{E}$ & - & + & - & . \\
\hline $35 \mathrm{E}$ & - & + & - & . \\
\hline $40 \mathrm{FE}$ & - & + & - & . \\
\hline $40 \mathrm{HE}$ & - & + & - & . \\
\hline R10E & - & + & - & . \\
\hline $4051 \mathrm{CO}$ & - & + & - & . \\
\hline $4211 \mathrm{CO}$ & - & + & - & . \\
\hline 34497 CO & - & + & - & . \\
\hline $34498 \mathrm{CO}$ & - & + & $\pm *$ & . \\
\hline $41483 \mathrm{CO}$ & - & + & - & . \\
\hline $41484, \mathrm{CO}$ & - & + & - & . \\
\hline 4678 & - & $\pm *$ & + & . \\
\hline Newson & - & $=$ & - & 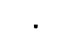 \\
\hline
\end{tabular}

Similar results by type-precipitin reaction with $\mathrm{HCl}$ and formamide extracts, slide and water-bath agglutination.

* Cross-reactions.

$\uparrow$ Represented by strain Newson.

Type II. Fourteen strains (K131, TY 7 and those labelled E and CO) fell into this type. They all absorbed the homologous antibodies from at least one serum and most of them from two of the three available sera.

This type was previously identified by Coffey (1942); she noticed that her six strains (strains $\mathrm{CO}$ ) were members of the same type as strain K131, which is confirmed here.

Some particular characteristics of the sera are worth considering. Serum 312 against $4211 \mathrm{CO}$, with the low end-titre of $1 / 320$, was type-specific and gave comparable results with the different tests and extracts. Serum 308, prepared against $\mathrm{K} 131$, varied in that the first bleeding was completely typespecific by the precipitin reaction, while the second bleeding showed crossreactions with heterologous groups and a staphylococcus extract; however, 
both bleedings were non-specific by slide-agglutination. By diluting the serum to titre by the dropping method, the cross-reactions could be avoided without the need of further absorptions. Reactions with the serum 227 against TY 7 also gave interesting data: the sixth bleeding was type-specific, but the previous one reacted with A and G groups; however, in contrast to serum 308, it was not made type-specific by dilution to titre. This seems to be directly related to the agglutinin content because, whereas the successfully diluted serum 308 had a titre of $1 / 640$, the present serum had a titre of only $1 / 160$.

Type III. This type was formed by the single strain 4678. Its homologous antiserum 294 was found to be type-specific in the first three bleedings but showed group specificity in the fourth bleeding. However, sera of all these bleedings cross-reacted by slide agglutination with strains of type I. On account of low agglutinin content $(1 / 80)$ dilution to titre did not eliminate the heterologous reactions, but the serum was rendered specific by heterologous absorption.

Type antigen characteristics of Streptococcus subacidus

Since at least the Streptococcus subacidus strains K128 and 34498 CO fell into distinct serotypes of $S$. infrequens, it was at first concluded that no relationship was found between the biochemical and the antigenic differentiation of these two species. However, in assessing the type antigenic behaviour of the $S$. subacidus strains, evidence may be brought to prove that the two streptococci are antigenically dissimilar. Thus, the $S$. subacidus 4678 showed that, while forming a distinct type of its own (type III), it also reacted by precipitin and agglutinin tests with the three different sera prepared against strains of type II. This strain 4678 also totally exhausted all the antisera of their type II agglutinins. Tests were repeated several times, and it was observed that absorption was always complete with doses equal to the minimal absorbing doses of the homologous organisms. It seems possible, therefore, that $S$. subacidus possesses at least two type antigens of which only one is shared by $S$. infrequens. It is interesting to note that these findings agree with an early observation of Minett \& Stableforth (1934), who mentioned that $S$. infrequens shows only one of the two antigens exhibited by the 'low acid streptococci', the designation given by them to $S$. subacidus.

\section{Antigenic complex}

Hirst \& Lancefield (1939) have stated that cocci from group A could be extracted by hot $\mathrm{HCl}$ more than once. There is reason to believe that it will be so with other serological groups and experience has confirmed that all the twenty haemolytic strains examined here can be satisfactorily extracted at least three times. This procedure was followed in the hope that it might bring about some evidence of the nature and distribution of the different antigenic substances in the cells of the group here concerned.

Ethanol fractionation was applied to crude $\mathrm{HCl}$ extracts of seven strains from three different serotypes and against which homologous type sera were available (Table 3 ). It was observed that, while the protein precipitates of the 


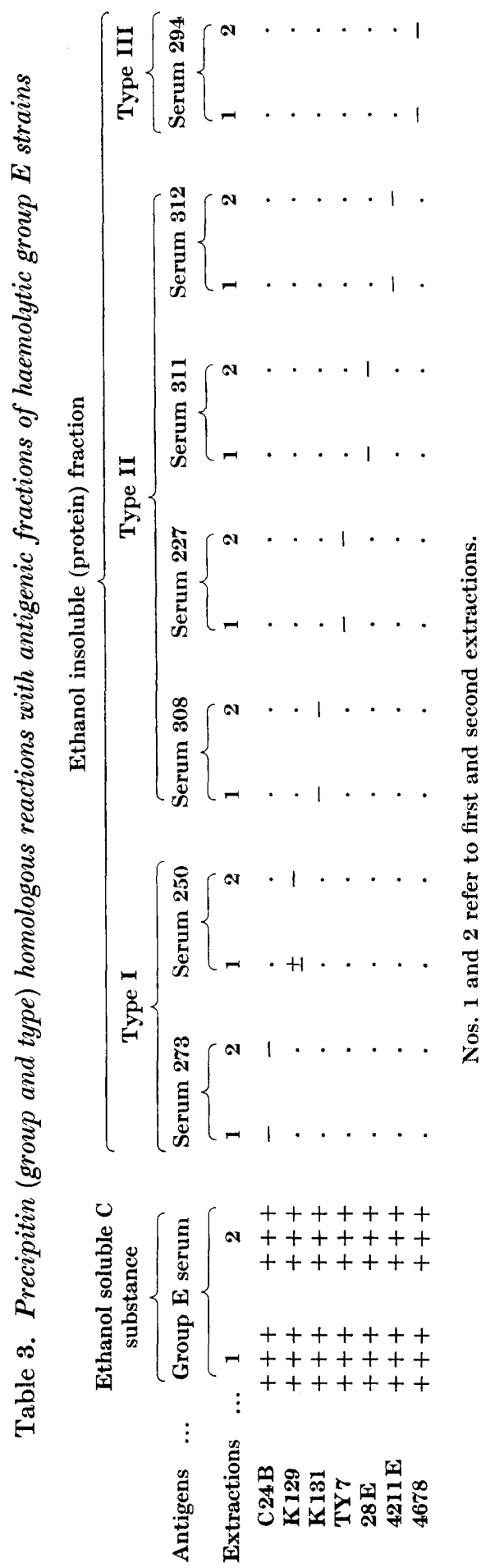


second extractions were obtained carbohydrate-free after three ethanol washings, the precipitates of the first extractions only showed purity after the fourteenth ethanol treatment. This may mean that the amount of protein is greatest at the surface of the bacterial cells. The $\mathrm{C}$-substance solutions obtained from the repeated extractions of all the haemolytic strains gave typical carbohydrate rings in the presence of group $\mathbf{E}$ antisera. As the reaction was consistently positive, it seems that the substance responsible for group-specificity is polysaccharide in nature. Most of these solutions of multiple extraction induced the formation of ring precipitates of similar intensity when geometrically diluted from $1 / 2$ to $1 / 16$, suggesting that the group substance exists not only at the surface but also on the subsurface portions of the cells. None of the protein fraction solutions gave any reaction with its homologous serum, and the conclusion may be drawn that the type-specific fraction was dissolved by the ethanol and is, like the group substance, of polysaccharide nature. Two factors may corroborate these findings: first, the parallelism found in the order of antibody appearance in the serum induced by the streptococci of group $\mathrm{E}$ and of group B which, as proved by Lancefield (1934, 1938) have also a polysaccharide as the type-specific substance. Secondly, it was possible to type strains of group $\mathrm{E}$ by using formamide extracts - solutions of polysaccharide-which react with sera deprived of group antibodies. Lancefield (1940-1) also stated that of groups other than A, B or C, less is known about the type-specific substances, but the evidence suggests that polysaccharides are chiefly concerned.

\section{Preparation of antisera for serological group $E$}

In the preparation of antiserum for group E, hyper-immunization must be avoided as group antibodies may appear soon after the first inoculations and before type-specific antibodies. This peculiarity is probably responsible for the difficulties experienced in the preparation of this antiserum. In fact, it happened that two samples of sera from different sources and labelled 'group $\mathbf{E}$ specific' proved to be only specific for serotype II. No substantial difference could be found between heat-killed and formolized immunizing suspensions.

During the attempts at serum absorption the selection of a satisfactory absorbing strain was one of the main difficulties encountered. As reported by Eisman (quoted by Krumwied, 1943) absorbing sediments could be used more than once if they were washed and heated at $100^{\circ}$ after use. The absorbing power of the heterologous crossing strains varied considerably, but no difference was found between the use of heat-killed, formol-killed or live cocci. Group agglutinins were present in sera shown to be specific by the type-precipitin reaction, but these sera may in fact contain $\mathrm{C}$ antibodies before group antibody can be detected. Nucleoprotein $\mathrm{P}$ seems also to play a part in cross-agglutination, although, like the $\mathrm{C}$ substance, not consistently; thus, while one group $\mathrm{E}$ antiserum with $\mathbf{P}$-antibodies showed group agglutination, another similar one proved to be completely type-specific, an observation supported by Lancefield (1940-1). 


\section{DISCUSSION}

The confusion in the terminology of the organisms here concerned, especially Streptococcus infrequens, deserves some attention. The term $\boldsymbol{S}$. infrequens was originated by Holman (1916) for a group of haemolytic strains of infrequent occurrence, isolated from human pathogenic conditions, fermenting lactose, mannitol and salicin. Brown, Frost \& Shaw (1926) also described two strains of $S$. infrequens isolated from sporadic cases of human septicaemia and pneumonia respectively. The name $S$. subacidus was also used by Holman (1916) for those pathogenic strains which showed no action with the three sugars tested. Holman's contentions regarding the pathogenicity of these organisms were generally supported by contemporary workers.

Later, Frost, Gumm \& Thomas (1927) applied these names to haemolytic strains isolated from milk which were biochemically similar to Holman's streptococci. The descriptions were thereafter generally used by authors, e.g. Sherman (1937), dealing with dairy bacteriology. In the light of the present knowledge, it is clear that no relationship exists between the human pathogenic strains and the haemolytic streptococci from milk which fall into group E.

So far, strains belonging to group $\mathrm{E}$ have not been reported in man, in health or disease. According to the work of several authors quoted by Pike \& Fashena (1946), no streptococci of this group were found in over 25,000 swabs from men in many parts of the world. The investigations of Plummer (1941) in Canada and Gunnison et al. (1940) in America were similarly negative. The strain isolated by Coffey (private communication) from a suppurating wound in the hand of a dairy worker was probably an accidental association with an infection of staphylococcal origin, as large numbers of these organisms were also present. More detailed information is also necessary before a sound conclusion can be drawn regarding the aetiological relation of group E streptococci with pathological conditions in pigs (Stafseth \& Clinton, 1941, Collier, 1951). It is reasonable to consider the haemolytic strains of group $\mathbf{E}$ as non-pathogenic, their normal habitat being milk (Topley $\&$ Wilson's Principles, 1946).

In order to re-adjust the term to its former pathogenic and human relationship, Brown (1939) presented Streptococcus infrequens as a member of group A, including in it the pyogenic strains which ferment lactose, mannitol, salicin and trehalose, but not sorbitol. For group $\mathrm{E}$ he proposed the name $S$. lentus to indicate that these organisms grow slowly and in minute colonies. Undoubtedly this unnecessarily confuses the issue. In the first place, slow growth is not a characteristic of group $\mathrm{E}$ streptococci; both stock and recently isolated strains have shown, in this respect, similarity with other streptococci. Thus, to avoid confusion by creating a new expression, it seems more reasonable to retain the designation for haemolytic milk strains of group $\mathbf{E}$ and to adhere to a principle already established.

Streptococcus infrequens is an organism of well-defined biochemical characteristics. The results of this work are similar to those recorded by most of the workers on this organism (Minett \& Stableforth, 1934; Gunnison et al. 1940, 
and Coffey, 1942). The characteristics given in Bergey's Manual (1948) for group $\mathrm{E}$ streptococci are also concordant, but they are presented together with those of $S$. subacidus. S. subacidus seems similar in all respects to the haemolytic 'low acid streptococcus' isolated from milk and described by Minett \& Stableforth (1934).

I am greatly indebted to Dr A. T. R. Mattick for his valuable suggestions and helpful criticism throughout this work; he was also kind enough to help in the preparation of the manuscript. Thanks are also due to Dr P. M. Frances Shattock for good advice in points of technique and continued interest.

\section{REFERENCES}

Bergey's Manual of Determinative Bacteriology (1948). 6th ed., edited by BREED, R. S., Murray, E. G. D. \& Hitchens, A. P. London: Baillière, Tindall and Cox.

Brown, J. H. (1939). The taxonomy of streptococci. III Congr. int. Microbiol. p. 172. New York.

Brown, J. H., Frost, W. D. \& Shaw, M. (1926). Hemolytic streptococci of the beta type in certified milk. J. infect. Dis. $38,381$.

CofFey, J. (1942). Hemolytic streptococci of serologic group E. J. Bact. 43, 773.

Collier, J. R. (1951). A survey of the beta-hemolytic streptococci from swine. Proc. Amer. vet. med. Ass. p. 169.

Davis, J. G., McClemont, J. \& Rogers, H. J. (1939). Studies on mastitis. J. Dairy Res. 10, 59.

DE WAAL, H. L. (1940). The serological types of haemolytic streptococci in relation to the epidemiology of scarlet fever and its complications. J. Hyg., Camb., 40, 172.

Frost, W. D., Gumm, M. \& Thomas, R. C. (1927). Types of hemolytic streptococci in certified milk. J. infect. Dis. 40, 698.

Fuller, A. T. (1938). The formamide method for the extraction of polysaccharide from haemolytic streptococci. Brit. J. exp. Path. 19, 130.

Gunnison, J. B., Luxen, M. P., Marshall, M. S. \& Engle, B. Q. (1940). Hemolytic streptococci in raw market milk. J. Dairy Sci. 23, 447.

Hirst, G. K. \& Lancefield, R. C. (1939). Antigenic properties of the type-specific substance derived from group A hemolytic streptococci. J. exp. Med. 69, 425.

Holman, W. L. (1916). The classification of streptococci. J. med. Res. 34, 377.

Krumwied, E. (1943). A comparison of the value of the agglutination and precipitin reactions in the serological typing of group A streptococci. J. Bact. 46, 117.

LANCEFIELD, R. C. (1933). A serological differentiation of human and other groups of hemolytic streptococci. J. exp. Med. 57, 571.

LANCEFIELd, R. C. (1934). A serological differentiation of specific types of bovine hemolytic streptococci (group B). J. exp. Med. 59, 441.

LANCEFIELD, R. C. (1938). Two serological types of group B hemolytic streptococci with related, but not identical, type-specific substances. J. exp. Med. 67, 25.

LANCEFIELD, R. C. (1940-1). Specific relationship of cell composition to biological activity of hemolytic streptococci. Harvey Lect. 36, 251.

Minett, F. C. \& Stableforti, A. W. (1934). Non-pathogenic haemolytic streptococci occurring in milk. J. Dairy Res. 5, 223.

Newson, I. E. (1937). Strangles in hogs. Vet. Med. 37, 137.

Pike, R. M. \& Fashena, G. J. (1946). Frequency of hemolytic streptococci in the throats of well children in Dallas. Amer. J. publ. Hlth, 36, 611.

Plummer, H. (1941). A serological and biochemical study of hemolytic streptococci. J. Immunol. 42, 91. 
Shatrock, P. M. F. \& Hirsch, A. (1947). A liquid medium buffered at pH $9 \cdot 6$ for the differentiation of Streptococcus faecalis from Streptococcus lactis. J. Path. Bact. $59,495$.

Shattock, P. M. F. \& Mattick, A. T. R. (1943). The serological grouping of Streptococcus lactis (group N) and its relationship to Streptococcus faecalis. J. Hyg., Camb., 43, 173.

Sherman, J. M. (1937). The streptococci. Bact. Rev. $1,3$.

Stafseth, H. J. \& Clinton, I. (1941). Lancefield group E streptococci in cervical abscesses of swine. J. Amer. vet. med. Ass. 99, 468.

Swift, H. F., Wilson, A. T. \& LaNCEField, R. C. (1943). Typing group A hemolytic streptococci by $\mathrm{M}$ precipitin reactions in capillary pipettes. J. exp. Med. 78, 127.

Thal, E. \& Moberg, K. (1953). Serologische Gruppenbestimmung der bei Tieren vorkommenden $\beta$-haemolytischen Streptokokken. Nord. VetMed. 5, 835.

Topley \& Wilson's Principles of Bacteriology and Immunity (1946). 3rd ed., p. 576. Revised by Wilson, G. S. \& Mrles, A. A. London: Ed. Arnold and Co.

(Received 18 August 1955) 